\author{
한국 전통 양념을 이용한 발효 돼지고기의 품질 특성 \\ 진상근*** . 김철욱* . 이상원*** . 송영민* . 김일석* . 박석규**** . 하경희** . 배대순***** \\ 진주산업대학교 동물소재공학과*, 진주산업대학교 동물생명산업연구센터**, \\ 진주산업대학교 미생물공학과***, 순천대학교 식품영양학과****, 진주교육청*****
}

\title{
Quality Characteristics of Fermented Pork with Korean Traditional Seasonings
}

\author{
S. K. Jin*,**, C. W. Kim*, S. W. Lee***, Y. M. Song*, I. S. Kim*, S. K. Park****, \\ K. H. Hah** and D. S. Bae***** \\ Department of Animal Resources Technology, Jinju National University*, Regional Animal Industry \\ Research Center, Jinju National University**, Department of Microbiological Engineering, Jinju \\ National University***, Department of Food and Nutrition, Sunchon National University****, \\ Jinju Office of Educational Secton, Gyeongsangnamdo*****
}

\begin{abstract}
This study was carried out to evaluate the quality characteristics of the fermented pork with Korean traditional seasonings. The samples, outside muscle of pork ham were cut to cube $(7 \times 12 \times 2 \mathrm{~cm})$ and five Korean traditional seasonings such as garlic paste(T1), pickled Kimchi(T2), pickled Kimchi juice(T3), soybean paste(T4), red pepper paste(T5) were seasoned by the proportions of meat to seasonings $(1: 1)$. The seasoned samples were fermented at $-1 \pm 1{ }^{\circ} \mathrm{C}$ for 20 days. According to proximate composition analysis, all pork samples contained protein $20 \sim 22 \%$, fat $3 \sim 5 \%$, moisture $64 \sim 70 \%$ and ash $1.8 \sim 2.0 \%$. However, T5 had high crude fat level and relatively low moisture content. The highest $\mathrm{pH}$ among treatments was shown in $\mathrm{T} 1$ whereas T3 showed the lowest. Water holding capacity(WHC) of $\mathrm{T} 4$ and $\mathrm{T} 5$ were higher, while those values were lower in T3 compared with other treatment. Shear force value was the highest in T5, while it was the lowest in T4. TBARS value of T3 was the highest, while that was the lowest in T4. Moreover the highest VBN value was observed in T4 due to fermentation of soy protein. However, the lowest VBN value shown in $\mathrm{T} 1$ indicated the inhibition of protein degradation by the garlic. The highest saccarinity was shown in T5 but it was the lowest of in T3. Salinity was shown to be high in T2 and low in T5. L* values of T4 was higher both at the surface and inner side of samples than the others but T5 showed the lowest value. T2 showed the highest $a^{*}$ value but $\mathrm{T} 4$ and $\mathrm{T} 5$ showed the lowest. In the result of sensory evaluation for cooked meat, T5 had the highest score in all item including overall acceptability, while T4 had the lowest score. Unsaturated fatty acid(UFA) ratio of T5 and T2 were 72.16 and 69.93 respectively, and the ratio of UFA/Saturated fatty acid(SFA) were higher in the order of $\mathrm{T} 5>\mathrm{T} 4>\mathrm{T} 3>\mathrm{T} 1>\mathrm{T} 2$. Overall quality characteristics were higher in the order of $\mathrm{T} 5>\mathrm{T} 2>\mathrm{T} 1>\mathrm{T} 4>\mathrm{T} 3$.
\end{abstract}

(Key words : Fermented pork, Korean traditional seasonings, Quality characteristics, TBARS, VBN, Fatty acid)

Corresponding author : S. K. Jin, Department of Animal Resources Technology, Jinju National University, 660750, Jinju, Korea. Tel : 82-55-751-3283, Fax : 82-55-751-3514, E-mail : skjin@jinju.ac.kr 


\section{$\mathrm{I}$ 서 론}

수입 자유화로 인해 국내외 고기의 유통 환 경은 급변하고 있으며, 특히 돈육의 경우 구 제역 발생 이후 대일 수출 중단에 따라 수출 용 부위인 뒷다리, 앞다리, 등심, 안심 등의 재고가 누적되고 있어 양돈산업 자체의 큰 문 제점으로 대두되고 있다. 한국육류유통수출입 협회(2003)가 발표한 금년 9월말 현재 수출 부위인 4 부위의 추정재고는 19,033톤으로 매 우 많으며, 돼지고기 총 재고량 30,816톤의 $62 \%$ 에 해당되는 물량이라고 밝혔다. 이러한 수출 부위의 소진을 위해서는 무엇보다도 소 비자들이 선호할 수 있도록 만드는 것이 중요 하다 하겠다. 국내 소비자들이 수출 부위를 꺼려하는 이유인 구울 때 퍽퍽하고 단단하며 즙기가 없는 단점을 해결한다면 그 소비는 촉 진될 수 있을 것이다. 이러한 문제점들을 개 선시키기 위한 방법으로는 염지액 주입, 발효 숙성, 효소제 첨가에 의한 연화 등을 들 수 있다. 발효육은 자가숙성에 의하여 이루어지 며 이에 의하여 발생하는 근육의 변화로는 근 육단백질에 있어서 폴리펩타이드 체인의 응고 에 의한 근섬유 단백질의 용해성 감소(Crepo 등, 1978)와 체인의 일부가 절단되면서 연해 짐은 물론 유리아미노산, 핵산 및 관련물질, 아민류, 암모니아, 크레아틴 등 비단백태 질소 화합물이 증가하여 제품은 독특한 맛과 향을 내게 되며(Dierick 등, 1974), 또한 지방도 분 해되어 키톤알데하이드, 알코올류로 변하여 방향성 증진에 기여하게 된다(Whitaker, 1978). 우리 고유의 전통 발효 식품인 된장, 고추장 및 김치는 오래 전부터 식생활에 중요한 기본 조미식품으로 널리 이용되어 왔으며 최근 그 수요가 증가하고 있는 추세이다. 대두발효식 품인 된장은 영양원 뿐만 아니라 생리활성도 갖고 있어 고혈압 방지효과, 항돌연변이성, 항 암성, 혈전용해능은 대두에서 기인되는 protease inhibitor, phytic acid 및 isoflavones 등에 의해 기인되는 것으로 알려져 있다(Chung 등, 1996). 고추장은 전통적인 대두 발효 식품으 로 제조과정 중 amylase의 당화작용으로 인하
여 생성된 당의 단맛, protease의 단백질 분해 작용으로 생성된 아미노산의 구수한 맛, lipase의 작용으로 생성된 지방산과 고춧가루 의 매운맛 및 소금의 짠맛이 어우러져 특유의 맛을 이룬다. 김치는 비타민과 미네랄을 많이 함유하며, 특히 비타민 $\mathrm{C}$ 와 $\mathrm{Ca}$ 이 많이 들어 있으며, 항암효과, 독성물질 제거효과 및 항돌 연변이 효과가 있다(허, 1996). 이러한 우리의 전통적인 양념을 이용하여 고기에 접목시켜 퓨전화 함으로써 저장성 증진과 함께 발효에 의한 관능적 품질에도 좋은 영향을 미칠 것으 로 기대되나 발효 돼지고기에 대한 체계적인 연구가 없는 바, 본 연구는 한국 전통 양념을 이용한 발효 돼지고기의 물리화학적 및 관능 적 품질 특성에 미치는 영향을 조사하기 위하 여 실시하였다.

\section{ㅍ 재료 및 방법}

\section{1. 공시재료 및 양념 배합비}

돼지를 도축후 24시간 냉각된 지육중에서 농 림부가 고시한 가공기준에 준하여 뒷다리 부위 중 바깥 볼깃살을 채취하여 과다한 지방을 제 거하였다. 준비한 시료들을 $7 \times 12 \times 2 \mathrm{~cm}$ 크기 로 자른 후 Table 1 과 같이 개발된 배합비에 따라 $\mathrm{T} 1, \mathrm{~T} 4, \mathrm{~T} 5$ 의 양념액을 제조하였다. 김치 를 제조하여 김치 사이사이에 원료육을 넣어 발효시킨 처리구가 $\mathrm{T} 2$ 이며, $\mathrm{T} 3$ 는 제조된 김치 를 잘게 갈아 사용하였고 양념액과 육의 비율 은 $1: 1$ 로 하여 침지한 후 $-1 \pm 1^{\circ} \mathrm{C}$ 서 20 일간 저장하면서 실험 재료로 공시되었다. 품질 측 정 시 표면에 묻어 있는 양념은 흐르는 물로 한 번 씻은 후 물기를 닦아낸 다음 품질 측정 에 이용하였다.

\section{2. 분석방법}

\section{(1) 일반성분}

육의 일반성분은 $\mathrm{AOAC(1998)}$ 방법에 따라 수분은 건조법, 조단백질은 Kjeldahl법, 조지방 은 Soxhlet 추출법, 조회분은 $550^{\circ} \mathrm{C}$ 전기로 회 
Table 1. Formula of fermented pork products containing pickled Kimchi and Korean traditional seasoned paste containing soybean, garlic and red pepper

\begin{tabular}{|c|c|c|c|c|c|}
\hline \multirow{2}{*}{ Ingredients } & \multicolumn{5}{|c|}{ Teatmeant*(\%) } \\
\hline & $\mathrm{T} 1$ & $\mathrm{~T} 2$ & T3 & $\mathrm{T} 4$ & T5 \\
\hline Soybean paste & - & - & - & 28 & - \\
\hline Red pepper paste & - & - & - & - & 37 \\
\hline Pickled cabbage & - & 63 & $\begin{array}{c}64 \\
\text { (chopped) }\end{array}$ & - & - \\
\hline Sticky rice starch & - & 2 & 6 & - & - \\
\hline Pickled shrimp & 12 & 4 & 4 & - & - \\
\hline Pickled sea food & - & - & 6 & - & \\
\hline Powder red pepper & - & 3 & 6 & - & - \\
\hline Onion & 19 & 10 & - & 10 & - \\
\hline Radish & 18 & - & - & 19 & - \\
\hline Garlic & 17 & 3 & 4 & 8 & 4 \\
\hline Ginger & 9 & 2 & 1 & 3 & - \\
\hline Corn syrup & 25 & 1 & - & 20 & 20 \\
\hline Pear & - & 3 & 7 & - & - \\
\hline Glue plant & - & $\begin{array}{c}2 \\
\text { (fresh) }\end{array}$ & $\begin{array}{c}1 \\
\text { (dried) }\end{array}$ & - & - \\
\hline Red mustard leaf & - & - & 1 & - & \\
\hline Pineapple & - & - & - & 7 & 11 \\
\hline Ethyl alcohol & - & - & - & 2 & 2 \\
\hline Water & - & 7 & - & 3 & 26 \\
\hline Total & 100 & 100 & 100 & 100 & 100 \\
\hline
\end{tabular}

* T1; garlic paste, T2; pickled Kimchi, T3; pickled Kimchi juice, T4; soybean paste, T5; red pepper paste.

화법을 이용하여 측정하였다.

(2) $\mathrm{pH}$

근막, 지방 등을 제거한 후 세절한 시료 $10 \mathrm{~g}$ 을 증류수 90m 나 함께 homogenizer(MSE, U.S.A.)로 $14,000 \mathrm{rpm}$ 에서 1 분간 균질하여 $\mathrm{pH}-$ meter (Metrohm 632, Swiss)로 측정하였다.

(3) 보수력

마쇄한 시료를 $70^{\circ} \mathrm{C}$ 항온수조에서 30 분간
가열한 다음 냉각하여 $1,000 \mathrm{rpm}$ 에서 10 분간 원심분리한 후 무게를 측정하였다.

$$
\text { 보수력(\%) }=\frac{\text { (총 시료중량 }- \text { 유리수분 중량) }}{\text { 총 시료중량 }} \times 100
$$

(4) 전단력

전단력은 Rheometer(EZtest, shimadze, Japan) 를 이용하여 shearing cutting test로 근섬유와 평 행하게 두께와 직경이 $10 \mathrm{~mm}$ 와 $50 \mathrm{~mm}$ 가 되도록 절단하고 분석조건은 chart speed $120 / \mathrm{mm} / \mathrm{min}$, 
maximum load $10 \mathrm{~kg}$, 측정속도 $20 \mathrm{~mm}$, 시료높이 $20 \mathrm{~mm}$, adapter No. 4로 측정하였다.

\section{(5) 육색}

표면 육색은 고기의 표면에 묻어 있는 소스 를 칼등으로 제거한 다음 chromameter (Minolta Co. CR 301, Japan)를 이용하여 동일한 방법으 로 5회 반복하여 측정하여 명도(lightness)를 나 타내는 $\mathrm{L}^{*}$ 값, 적색도(redness)를 나타내는 $\mathrm{a}$ *값 과 황색도(yellowness)를 나타내는 $b^{*}$ 값을 측정 하였다. 이때 표준색은 $\mathrm{L}^{*}$ 값이 89.2, a*값이 $0.921, \mathrm{~b}$ *값이 0.783 인 표준색판을 사용하여 표 준화한 다음 측정하였다.

\section{(6) 관능검사}

관능검사는 잘 훈련된 관능검사요원 10 명을 선발하여 각 시험구별로 9점 척도법으로 관능 검사를 실시하였으며, aroma, flaovr, color, juiciness, tenderness, overall palatability의 항목으 로 관능검사를 실시하였다.

\section{(7) TBARS}

Buege와 Aust(1978)의 방법으로 시료 $5 \mathrm{~g}$ 에 butylated hydroxyanisole(BHA) 50ul와 증류수 $15 \mathrm{~m} \ell$ : 가해 polytorn homogenizer(MSE, U.S.A) 로 $14,000 \mathrm{rpm}$ 에서 30 초간 균질화 시킨 후 균 질액 $1 \mathrm{~m} \ell$ 을 시험관에 넣고 여기에 $2 \mathrm{~m} \ell$ thiobarbituric acid(TBA)/trichloroacetic acid(TCA) 혼합용액을 넣어 완전히 혼합한 다음, $90^{\circ} \mathrm{C}$ 항온수조에서 15 분간 열처리한 후 냉각시켜 $3,000 \mathrm{rpm}$ 에서 10 분간 원심분리시켰다. 원심분 리한 시료의 상층을 회수하여 spectrophotometer $531 \mathrm{~nm}$ 에서 흡광도를 측정하였다.

$$
T B A R S=\text { 흡광도 수치 } \times 5.88
$$

\section{(8) VBN}

高坂(1975)의 방법을 이용하여 세절육 $10 \mathrm{~g}$ 에 증류수 $90 \mathrm{~m} \ell$ 를 가하여 $14,000 \mathrm{rpm}$ 으로 5 분간 균질한 후 균질액을 whatman No. 1으로 여과하 여 여과액 $1 \mathrm{~m} \ell$ 를 conway unit 외실에 넣고 내 실에는 $0.01 \mathrm{~N}$ 붕산용액 $1 \mathrm{~m} \ell$ 와 지시약 $(0.066 \%$ methyl red $+0.066 \%$ bromocresol green)을 3방 울 가한다. 뚜껑과의 접착부위에 glycerine을 바 르고 뚜껑을 닫은 후 $50 \% \mathrm{~K}_{2} \mathrm{CO}_{3} 1 \mathrm{~m} \ell$ 를 외실 에 주입 후 즉시 밀폐시킨 다음 용기를 수평으 로 교반한 후 $37^{\circ} \mathrm{C}$ 서 120 분간 배양하였다. 배양 후 $0.02 \mathrm{~N} \mathrm{H}_{2} \mathrm{SO}_{4}$ 로 내실의 붕산용액을 측 정하였다.

(9) 염도와 당도

시료를 일정량 희석하여 당도계(ATAGO PR101, Japan)와 염도계(Takemura, TM-30D, Japan) 로 측정하였다.

(10) 지방산

지질 추출은 Folch(1957)의 방법으로 시료 $50 \mathrm{~g}$ 에 Folch 용액 $\left(\mathrm{CHCl}_{3}: \mathrm{CH}_{3} \mathrm{OH}=2: 1\right)$ 을 넣 고 균질화하여 지질을 추출한 후 가수분해하고 methylation 시킨 후 GLC를 이용하여 분석하였 으며, GLC 조건은 Table 2와 같다.

Table 2. GLC conditions for analysis of fatty acid

\begin{tabular}{ll}
\hline Item & \multicolumn{1}{c}{ Conditions } \\
\hline \hline Instrument & $\begin{array}{c}\text { Hewlett Packard 6890 } \\
\text { Gas chromatography }\end{array}$ \\
Column & HP-5 5MS fused silica capillary \\
& column 30m $\times 0.25$ i.d \\
Temperature & $2^{\circ} \mathrm{C}$ in \\
program & \\
Detector & Flame Ionization Detector(FID) \\
Split ratio & $90: 1$ \\
\hline
\end{tabular}

\section{3. 통계처리}

이상의 실험에서 얻어진 결과는 SAS(1999)의 GLM(General Linear Model) 방법으로 분석하였 고 처리 평균간의 비교를 위해 Duncan의 Multiple Range Test가 이용되었다.

\section{III 결과 및 고찰}

\section{1. 발효 돼지고기의 일반성분}

전통양념을 이용한 발효 돼지고기의 일반성 분을 Table 3에 나타내었다. 
Table 3. Proximate composition analysis of fermented pork with Korean traditional seasonings at $0 \pm 1^{\circ} \mathrm{C}$ or 20 days.

\begin{tabular}{ccccc}
\hline Treatment $^{1)}$ & Moisture & $\begin{array}{c}\text { Crude } \\
\text { protein }\end{array}$ & $\begin{array}{c}\text { Crude } \\
\text { lipid }\end{array}$ & $\begin{array}{c}\text { Crude } \\
\text { ash }\end{array}$ \\
\hline \hline T1 & 69.45 & 20.58 & 3.81 & 1.84 \\
T2 & 66.72 & 21.75 & 3.79 & 1.94 \\
T3 & 68.23 & 21.66 & 3.78 & 1.96 \\
T4 & 68.08 & 22.17 & 3.80 & 2.03 \\
T5 & 64.38 & 22.31 & 4.66 & 2.03 \\
\hline
\end{tabular}

1) T1(Fermented pork ham with garlic paste),

T2(Fermented pork ham with pickled Kimchi),

T3(Fermented pork ham with pickled Kimchi juice),

T4(Fermented pork ham with soybean paste),

T5(Fermented pork ham with red pepper paste).

수분, 조단백질, 조지방 및 조회분은 각각 약 $64 \sim 69 \%, 20 \sim 22 \%, 3 \sim 5 \%, 1 \sim 2 \%$ 수준이 었다. T1은 수분이 $69.45 \%$ 로 가장 높은 반면 조단백질 함량(20.58\%)이 가장 낮았으며, $\mathrm{T} 5$ 는 수분이 $64.38 \%$ 로 가장 낮은 반면 조단백질 (22.31\%)과 조지방(4.66\%) 함량이 가장 높았다. 김 등(1998)은 4개회사에서 생산된 뒷다리 부위 의 일반성분 분석 결과, 수분은 75.36 $76.57 \%$, 조단백질은 $19.26 \sim 21.08$, 조지방은 $1.40 \sim 3.69$, 조회분은 $1.03 \sim 1.13 \%$ 범위였다고 보고하였다. 특히 수분 함량에서 많이 차이가
나는 것은 아마도 발효과정 중 이화학적 변화 에 의한 것과 함께 동 연구에서 사용된 것은 뒷다리부위 중에서 바깥볼깃살이지만, 김 등 (1998)이 사용한 부위는 일본 수출용인 신다 마 부위인 것도 수분 함량에 영향을 미치지 않았나 생각된다. 한편, 한국영양학회(1995)에 따르면 수분이 $63.6 \%$, 조단백질이 $18.5 \%$, 조 지방이 $16.5 \%$, 조회분이 $1.1 \%$ 로 보고되었고, Savell과 Cross(1988)는 육의 맛을 위해 최소한 의 근육내 지방 함량은 $3 \%$ 수준이 적당하다 고 하였다.

\section{2. 발효 돼지고기의 $\mathrm{pH}, \mathrm{WHC}$ 및 전단력}

전통양념을 이용한 발효 돼지고기의 $\mathrm{pH}$, 보 수력 및 전단력을 Table 4에 나타내었다.

양념반죽과 발효육의 $\mathrm{pH}$ 는 $\mathrm{T} 1$ 이 가장 높았 으며, T3가 가장 낮게 나타났는데 이는 농축된 김치액에 의해 발효과정 중 유산균의 증식이 많은 것에 기인하는 것으로 판단된다. $\mathrm{pH}$ 측정 결과는 숙성 60 일까지 된장은 7.0 까지 높아졌 으나 고추장은 숙성기간 내내 5.0으로 낮아졌 다는 이 등(1996)의 결과와 차이를 보였다. 또 한 20일 발효 숙성기간 동안 유산균이 우세를 보이면서 모든 구의 $\mathrm{pH}$ 를 낮추는 것으로 판단 된다. 신 등(1996)은 고추장의 유기산은 succinic acid, citric acid, lactic acid 순으로 많았다고 보 고하였다.

Table 4. $\mathrm{pH}, \mathrm{WHC}$ and shear force of fermented pork with Korean traditional seasonings at $0 \pm 1^{\circ} \mathrm{C}$ or 20 days

\begin{tabular}{ccccc}
\hline Treatment $^{1)}$ & $\mathrm{pH}($ paste $)$ & $\mathrm{pH}($ meat $)$ & WHC $(\%)$ & Shear force $\left(\mathrm{kg} / \mathrm{cm}^{2}\right)$ \\
\hline \hline T1 & $6.5 \pm 0.0^{\mathrm{A}}$ & $5.9 \pm 0.1^{\mathrm{A}}$ & $84.42 \pm 2.49^{\mathrm{B}}$ & $2,162 \pm 64^{\mathrm{B}}$ \\
$\mathrm{T} 2$ & $5.3 \pm 0.0^{\mathrm{C}}$ & $5.4 \pm 0.1^{\mathrm{B}}$ & $60.87 \pm 0.23^{\mathrm{C}}$ & $1,668 \pm 54^{\mathrm{C}}$ \\
$\mathrm{T} 3$ & $4.5 \pm 0.1^{\mathrm{D}}$ & $4.2 \pm 0.1^{\mathrm{C}}$ & $56.17 \pm 3.07^{\mathrm{D}}$ & $1,737 \pm 30^{\mathrm{C}}$ \\
T4 & $5.4 \pm 0.0^{\mathrm{B}}$ & $5.3 \pm 0.1^{\mathrm{B}}$ & $91.29 \pm 1.09^{\mathrm{A}}$ & $1,534 \pm 83^{\mathrm{D}}$ \\
T5 & $5.4 \pm 0.1^{\mathrm{B}}$ & $5.4 \pm 0.1^{\mathrm{B}}$ & $91.97 \pm 1.81^{\mathrm{A}}$ & $2,502 \pm 118^{\mathrm{A}}$ \\
\hline
\end{tabular}

${ }^{1)}$ T1(Fermented pork ham with garlic paste), T2(Fermented pork ham for pickled Kimchi), T3(Fermented pork ham with pickled Kimchi juice), T4(Fermented pork ham for soybean paste), T5(Fermented pork ham for red pepper paste).

A,B,C,D Means with different superscripts in the same column are significantly different $(\mathrm{P}<0.05)$. 
보수력은 $\mathrm{T} 4$ 와 $\mathrm{T} 5$ 에서 매우 높고 다음으로 $\mathrm{T} 1$ 에서 높아 돼지 뒷다리 부위의 퍽퍽함을 개 선하여 다즙성을 증대시키는 데 기여하였으며, 상대적으로 피클 처리한 두 구는 보수력이 낮 아 소금에 의해 탈수(dehydration)되는 결과를 초래하였다.

전단력은 $\mathrm{T} 5$ 가 가장 높고, $\mathrm{T} 4$ 가 가장 낮게 나타나 된장 발효에 의한 고기 단백질의 분 해가 촉진되는 결과였다. Bouton 등(1973)은 신선육의 경우 보수성이 높아지면 고기는 부 드러워져 연도가 좋아진다고 하였으나 본 연 구의 발효육의 경우 차이를 보였다. Brewer 등(2002)은 전단력과 관능상의 맛과 점착성과 는 각각 0.94 및 0.69 의 상관관계가 있다고 하였다.

3. 발효 돼지고기의 TBARS, VBN, 당도 및 염도

전통양념을 이용한 발효 돼지고기의 지방산 패도, 휘발성염기태질소화합물, 당도 및 염도를 Table 5에 나타내었다.

지방산패도(TBARS)는 김치를 이용한 $\mathrm{T} 2$ 와 $\mathrm{T} 3$ 에서 높게 나타났으며, $\mathrm{T} 4$ 가 가장 낮았다. 이는 된장 중의 페놀 화합물과 갈변물질의 항 산화작용에 의한 것으로 밝혀지고 있다(이 등, 1991). Brewer 등(1992)은 신선육의 경우 malonaldehyde의 양이 $0.2 \mathrm{mg} / \mathrm{kg}$ 이하 범위 신
선하다고 하였는데 본 실험에서는 발효에 의 해 지방산패도가 0.33 33 범위로 높게 나타 났다. 식육의 지방산패도가 높아지는 것은 지 방분해 효소 및 미생물 대사 등에 의해 지방 이 분해됨으로써 형성되는 분해물질에 의한 것이다(Brewer 등, 1992). 이(1974)는 마늘의 정유가 a-tocopherol보다 과산화물 생성과 유 리지방산의 생성 억제 효과가 더 크다고 보고 하였다.

휘발성염기태질소화합물(VBN)은 콩단백질의 발효에 의해 $\mathrm{T} 4$ 가 가장 높았으며, $\mathrm{T} 1$ 이 가장 낮아 단백질의 분해 억제력을 지니는 것으로 판단된다. 휘발성 염기질소에 의한 저장성 판 정에 있어서 생육 가식권의 한계는 $30 \mathrm{mg} \%$, 어 육의 경우는 18 $\mathrm{jmg} \%$ 라고 하였으며(高坂 1975), 우리나라 식품공전 상에 신선육의 경우 $20 \mathrm{mg} \%$ 이하로 규정하고 있다.

당도는 $\mathrm{T} 5$ 가 가장 높았으며, $\mathrm{T} 2$ 와 $\mathrm{T} 3$ 가 낮았 고, 염도는 $\mathrm{T} 2$ 가 가장 높았으며, $\mathrm{T} 5$ 가 가장 낮 았다.

\section{4. 발효 돼지고기의 표면 및 심부 육색}

전통양념을 이용한 발효 돼지고기의 표면 및 절단면 심부 육색을 Table 6에 나타내었다.

표면과 심부육색의 $\mathrm{L}^{*}($ Lightness)값은 $\mathrm{T} 4$ 가 가장 높고, $\mathrm{T} 5$ 가 가장 낮았다. 포장 후 저장 중 고추장의 경우 $\mathrm{L}^{*}$ 값은 감소하고, $\mathrm{a}^{*}$ 및 $\mathrm{b} *$ 값은

Table 5. TBARS, VBN, Saccarinity and Salinity of fermented pork Korean traditional seasonings at $0 \pm 1^{\circ} \mathrm{C}$ or 20 days

\begin{tabular}{ccccc}
\hline Treatment $^{1)}$ & TBARS(mg/kg) & VBN(mg\%) & Saccarinity(\%) & Salinity(\%) \\
\hline \hline T1 & $0.45 \pm 0.01^{\mathrm{C}}$ & $3.0 \pm 0.23^{\mathrm{D}}$ & $1.3 \pm 0.2^{\mathrm{A}}$ & $2.13 \pm 0.08^{\mathrm{B}}$ \\
T2 & $0.82 \pm 0.02^{\mathrm{B}}$ & $13.8 \pm 0.81^{\mathrm{C}}$ & $0.9 \pm 0.2^{\mathrm{B}}$ & $2.43 \pm 0.07^{\mathrm{A}}$ \\
T3 & $1.33 \pm 0.10^{\mathrm{A}}$ & $28.2 \pm 1.66^{\mathrm{B}}$ & $0.7 \pm 0.0^{\mathrm{B}}$ & $2.17 \pm 0.12^{\mathrm{B}}$ \\
T4 & $0.33 \pm 0.02^{\mathrm{D}}$ & $66.6 \pm 2.59^{\mathrm{A}}$ & $1.3 \pm 0.2^{\mathrm{A}}$ & $1.68 \pm 0.17^{\mathrm{C}}$ \\
T5 & $0.35 \pm 0.07^{\mathrm{CD}}$ & $29.7 \pm 0.25^{\mathrm{B}}$ & $1.5 \pm 0.2^{\mathrm{A}}$ & $1.59 \pm 0.16^{\mathrm{C}}$ \\
\hline
\end{tabular}

1) T1(Fermented pork ham with garlic paste), T2(Fermented pork ham with pickled Kimchi), T3(Fermented pork ham with pickled Kimchi juice), T4(Fermented pork ham with soybean paste), T5(Fermented pork ham with red pepper paste).

$\mathrm{A}, \mathrm{B}, \mathrm{C}, \mathrm{D}$ Means with different superscripts in the same column are significantly different $(\mathrm{P}<0.05)$. 
Table 6. Surface and inner meat color of fermented pork with Korean traditional seasonings at $0 \pm 1^{\circ} \mathrm{C}$ or 20 days

\begin{tabular}{cccccccc}
\hline \multirow{2}{*}{ Treatment $^{1)}$} & \multicolumn{3}{c}{ Surface meat } & & 3 & Inner meat \\
\cline { 2 - 3 } \cline { 6 - 7 } & $\mathrm{L}^{*}$ & $\mathrm{a}^{*}$ & $\mathrm{~b}^{*}$ & & $\mathrm{~L}^{*}$ & $\mathrm{a}^{*}$ & $\mathrm{~b}^{*}$ \\
\hline \hline $\mathrm{T} 1$ & $39.4 \pm 1.6^{\mathrm{B}}$ & $10.4 \pm 1.9^{\mathrm{C}}$ & $9.6 \pm 0.7^{\mathrm{D}}$ & & $39.1 \pm 0.5^{\mathrm{B}}$ & $12.9 \pm 0.4^{\mathrm{B}}$ & $12.0 \pm 0.4^{\mathrm{B}}$ \\
$\mathrm{T} 2$ & $39.6 \pm 2.9^{\mathrm{B}}$ & $16.5 \pm 1.8^{\mathrm{A}}$ & $22.0 \pm 1.4^{\mathrm{A}}$ & & $39.8 \pm 3.4^{\mathrm{B}}$ & $15.6 \pm 2.1^{\mathrm{A}}$ & $19.0 \pm 2.5^{\mathrm{A}}$ \\
$\mathrm{T} 3$ & $40.2 \pm 1.7^{\mathrm{B}}$ & $10.7 \pm 0.2^{\mathrm{C}}$ & $10.6 \pm 0.4^{\mathrm{D}}$ & & $40.2 \pm 2.0^{\mathrm{B}}$ & $13.2 \pm 0.4^{\mathrm{B}}$ & $12.8 \pm 0.4^{\mathrm{B}}$ \\
$\mathrm{T} 4$ & $46.6 \pm 2.2^{\mathrm{A}}$ & $13.7 \pm 0.5^{\mathrm{B}}$ & $14.1 \pm 1.4^{\mathrm{C}}$ & & $47.9 \pm 3.3^{\mathrm{A}}$ & $12.8 \pm 1.0^{\mathrm{B}}$ & $11.9 \pm 0.7^{\mathrm{B}}$ \\
$\mathrm{T} 5$ & $32.8 \pm 0.2^{\mathrm{C}}$ & $12.9 \pm 1.4^{\mathrm{BC}}$ & $17.4 \pm 1.8^{\mathrm{B}}$ & & $36.7 \pm 1.3^{\mathrm{B}}$ & $13.4 \pm 0.7^{\mathrm{B}}$ & $12.6 \pm 1.7^{\mathrm{B}}$ \\
\hline
\end{tabular}

${ }^{1)}$ T1(Fermented pork ham with garlic paste), T2(Fermented pork ham with pickled Kimchi), T3(Fermented pork ham with pickled Kimchi juice), T4(Fermented pork ham with soybean paste), T5(Fermented pork ham with red pepper paste).

A,B,C,D Means with different superscripts in the same column are significantly different $(\mathrm{P}<0.05)$.

증가를 보여 전체적으로 암갈색을 띄는 경향 을 보였다는 김 등(2000)의 결과와 일치하였 다. 표면과 심부육색의 $\mathrm{a}^{*}$ (Redness)값은 $\mathrm{T} 2$ 가 가장 높았으며, 다음으로 $\mathrm{T} 4$ 와 $\mathrm{T} 5$ 가 비슷한 수준으로 높았다. b*(Yellowness)값은 T2가 표 면 및 심부 육색에서 가장 높았다. 신선육의 육색은 매장에서 최초로 소비자가 구입을 결 정하게 하는 유일한 품질 특성으로 신선육 표 면에서 갈색 색소가 총 색소의 30 J\%에 도 달하게 되면 소비자들은 구매를 기피한다 (Greene 등, 1971).

\section{5. 가열 발효 돼지고기의 관능검사}

전통양념을 이용한 발효 돼지고기를 가열한
후에 평가한 관능검사 결과를 Table 7에 나타 내었다.

관능평가 결과 전 항목 및 전체적인 기호도 는 $\mathrm{T} 5$ 가 가장 높았으며, $\mathrm{T} 4$ 가 가장 낮았다. 육색, 다즙성, 연도 및 전체적인 기호도에 있 어 $\mathrm{T} 1, \mathrm{~T} 2, \mathrm{~T} 3$ 와 $\mathrm{T} 5$ 간에는 유의적인 차이를 보이지 않았다. 가열육의 풍미는 맛과 냄새를 종합하여 느껴지는 것으로 단백질과 지질의 분해 및 상호작용에 의해 발생되며 특히 육내 지방은 가열시 고기 특유의 풍미를 갖게 한다 (Mottram과 Edwards, 1983). 한편 다즙성은 지 방과 수분을 많이 보존하는 육일수록 높아 깊 은 상관관계를 갖고 있다(Carlin과 Harrison, 1978).

Table 7. Sensory evaluation of fermented and cooked pork with Korean traditional seasonings at $0 \pm 1^{\circ} \mathrm{C}$ or 20 days

\begin{tabular}{|c|c|c|c|c|c|c|}
\hline Treatment $^{1)}$ & Aroma & Flavor & Color & Juiciness & Tenderness & $\begin{array}{c}\text { Overall } \\
\text { palatability }\end{array}$ \\
\hline $\mathrm{T} 1$ & $6.2 \pm 0.8$ & $5.2 \pm 2.2$ & $5.2 \pm 2.6^{\mathrm{AB}}$ & $5.6 \pm 1.3^{\mathrm{A}}$ & $6.2 \pm 1.5^{\mathrm{A}}$ & $5.8 \pm 0.8^{\mathrm{AB}}$ \\
\hline $\mathrm{T} 2$ & $6.2 \pm 0.8$ & $5.0 \pm 1.6$ & $5.8 \pm 0.4^{\mathrm{AB}}$ & $6.0 \pm 1.2^{\mathrm{A}}$ & $6.4 \pm 0.9^{\mathrm{A}}$ & $6.0 \pm 0.7^{\mathrm{AB}}$ \\
\hline T3 & $5.0 \pm 1.7$ & $5.6 \pm 0.9$ & $4.8 \pm 0.8^{\mathrm{AB}}$ & $3.8 \pm 0.4^{\mathrm{B}}$ & $5.0 \pm 1.2^{\mathrm{AB}}$ & $5.8 \pm 1.3^{\mathrm{AB}}$ \\
\hline $\mathrm{T} 4$ & $5.4 \pm 0.9$ & $5.4 \pm 1.1$ & $4.6 \pm 0.9^{\mathrm{B}}$ & $4.2 \pm 0.4^{\mathrm{B}}$ & $4.2 \pm 1.1^{\mathrm{B}}$ & $5.2 \pm 1.1^{\mathrm{B}}$ \\
\hline T5 & $6.2 \pm 1.3$ & $6.6 \pm 1.1$ & $6.6 \pm 0.5^{\mathrm{A}}$ & $6.6 \pm 0.9^{\mathrm{A}}$ & $6.0 \pm 1.2^{\mathrm{A}}$ & $6.9 \pm 0.7^{\mathrm{A}}$ \\
\hline
\end{tabular}

${ }^{1)}$ T1(Fermented pork ham with garlic paste), T2(Fermented pork ham with pickled Kimchi), T3(Fermented pork ham with pickled Kimchi juice), T4(Fermented pork ham with soybean paste), T5(Fermented pork ham with red pepper paste).

${ }_{\mathrm{A}, \mathrm{B}}$ Means with different superscripts in the same column are significantly $\operatorname{different}(\mathrm{P}<0.05)$. 
Table 8. Fatty acid composition of fermented pork with Korean traditional seasonings at $0 \pm 1^{\circ} \mathrm{C}$ or 20 days

\begin{tabular}{ccccccccccc}
\hline \multirow{2}{*}{ Treatment $^{1)}$} & \multicolumn{10}{c}{ Fatty acid composition } \\
\cline { 2 - 10 } & C14:0 & C16:0 & C16:1 & C18:0 & C18:1 & C18:2 & C20:4 & UFA $^{2)}$ & SFA $^{3)}$ & UFA / SFA \\
\hline \hline T1 & 1.28 & 19.07 & 2.91 & 9.47 & 41.21 & 18.30 & 7.77 & 70.19 & 29.81 & 2.35 \\
T2 & 1.21 & 18.95 & 2.24 & 9.90 & 36.18 & 24.68 & 6.83 & 69.93 & 30.07 & 2.33 \\
T3 & 1.52 & 19.11 & 3.05 & 8.78 & 40.50 & 22.87 & 4.16 & 70.58 & 29.42 & 2.40 \\
T4 & 0.72 & 19.12 & 1.61 & 9.40 & 32.17 & 25.35 & 11.61 & 70.74 & 29.26 & 2.42 \\
T5 & 0.83 & 17.46 & 2.13 & 9.54 & 36.49 & 23.89 & 9.65 & 72.16 & 27.84 & 2.59 \\
\hline
\end{tabular}

1) T1(Fermented pork ham with garlic paste), T2(Fermented pork ham with pickled Kimchi), T3(Fermented pork ham with pickled Kimchi juice), T4(Fermented pork ham with soybean paste), T5(Fermented pork ham with red pepper paste).

${ }^{2)}$ UFA : unsaturated fatty acid, ${ }^{3)}$ SFA : saturated fatty acid.

\section{6. 발효 돼지고기의 지방산 조성}

전통양념을 이용한 발효 돼지고기의 지방산 조성을 Table 8에 나타내었다.

올레인산은 $\mathrm{T} 1$ 과 $\mathrm{T} 3$ 가 많고 $\mathrm{T} 4$ 는 적었고 리 놀산은 $\mathrm{T} 4$ 가 많고 $\mathrm{T} 1$ 이 적었으며, 아라키돈산 은 $\mathrm{T} 4$ 가 많고 $\mathrm{T} 3$ 가 적었다. 일반적으로 돈육에 서 지방산 함량은 올레인산, 팔미트산 순이라 는 보고(Kim 등, 1998) 되었는데 본 연구에서 는 올레인산 다음으로는 리놀산, 리놀렌산, 팔 미트산 순이었다. 한편 불포화지방산 비율은 $\mathrm{T} 5$ 가 많고 $\mathrm{T} 2$ 는 적은 반면 포화지방산 비율은 그 반대였다. 높은 포화지방산 비율은 육내 지 방산화 안정성 $(\mathrm{Du}$ 등, 2000, Sim, 1997) 및 육 색 안정성에 도움을 준다(Joo 등, 2002). 그러나 인체 건강과 관련한 지방산 조성면에서 동맥경 화증, 고혈압 예방 등과 같은 건강에 유익한 지방산은 불포화지방산 비율이 높고, 포화지방 산 비율이 낮을수록 좋다(Engler 등, 1991; Decker와 Shantha, 1994). 불포화지방산/포화지 방산 비율은 T5, T4, T1 순이었다.

$$
\mathrm{IV} \text { 요 약 }
$$

이 연구는 한국 전통 양념을 이용한 발효 돼 지고기의 품질 특성에 관한 것으로 돼지고기의 바깥 볼깃살을 채취하여 $7 \times 12 \times 2 \mathrm{~cm}$ 크기로 자른 후 육을 동일한 비율의 양념액에 침지하
여 $-1 \pm 1^{\circ} \mathrm{C}$ 서 20 일간 숙성한 발효육[T1(마 늘소스 돼지고기), $\mathrm{T} 2$ (제육김치 돼지고기), $\mathrm{T} 3$ (김치소스 돼지고기), $\mathrm{T} 4$ (된장소스 돼지고기), $\mathrm{T} 5$ (고추장소스 돼지고기)]의 품질 특성을 측정 한 결과는 다음과 같다. $\mathrm{T} 1$ 은 수분이 가장 높 은 반면 조단백질 함량이 가장 낮았으며, $\mathrm{T} 5$ 는 수분이 가장 낮은 반면 조단백질과 조지방 함 량이 가장 높았다. 양념 페이스트와 발효육의 $\mathrm{pH}$ 는 $\mathrm{T} 1$ 이 가장 높았으며, $\mathrm{T} 3$ 가 가장 낮게 나 타났다. 보수력은 $\mathrm{T} 4$ 와 $\mathrm{T} 5$ 가 매우 높고, $\mathrm{T} 3$ 는 가장 낮았다. 전단력은 $\mathrm{T} 5$ 가 가장 높고, $\mathrm{T} 4$ 가 가장 낮게 나타났다. 지방산패도는 $\mathrm{T} 3$ 가 가장 높았으며, $\mathrm{T} 4$ 가 가장 낮았다. 휘발성염기태질소 화합물은 $\mathrm{T} 4$ 가 가장 높았으며, $\mathrm{T} 1$ 이 가장 낮았 다. 당도는 $\mathrm{T} 5$ 가 가장 높았으며, $\mathrm{T} 3$ 가 가장 낮 았다. 염도는 $\mathrm{T} 2$ 가 가장 높았으며, $\mathrm{T} 5$ 가 가장 낮았다. 표면육색과 심부육색 모두 $\mathrm{L}^{*}$ 값, $\mathrm{a}$ *값, $\mathrm{b}$ *값은 각각 $\mathrm{T} 4, \mathrm{~T} 2, \mathrm{~T} 2$ 가 가장 높았으며, $\mathrm{L}^{*}$ 값은 $\mathrm{T} 5$ 가 가장 낮았다. 가열육의 관능평가 결 과 전 항목 및 전체적인 기호도는 $\mathrm{T} 5$ 가 가장 높았으며, T4가 가장 낮았다. 불포화지방산 비 율은 $\mathrm{T} 5$ 가 많고 $\mathrm{T} 2$ 는 적었다. 불포화지방산/포 화지방산 비율은 T5, T4, T3, T1, T2 순이었다. 종합적인 품질 특성에 있어 $\mathrm{T} 5, \mathrm{~T} 2, \mathrm{~T} 1, \mathrm{~T} 4, \mathrm{~T} 3$ 순이었다. 이상의 결과를 요약하여 볼 때, 소비 자가 구입을 꺼려하는 뒷다리살을 한국 전통양 념류를 이용하여 제품을 만들었을 때, 제품의 맛과 품질을 개선시켜 그 소비를 촉진 시킬 수 
있을 것으로 사료되며 앞으로 포장방법과 유통 기간 설정 등 이에 대한 더욱더 많은 연구가 이루어져야 하겠다.

$$
\mathrm{V} \text { 사 사 }
$$

본 연구는 한국과학재단 지정 진주산업대학 교 동물생명산업지역협력연구센터(과제번호: R122002-053-03003-0)의 연구비 일부 지원에 의한 것입니다.

\section{$\mathrm{VI}$ 인 용 문 헌}

1. A.O.A.C. 1998. Official methods of analyis. Association of official analytical chemist. Washinton, D.C.

2. Bouton, P. E., Carroll, F. D., Fisher, A. L., Harris, P. V. and Shorthose, W. R. 1973. Influence of $\mathrm{pH}$ and fiber contraction state upon factors affecting the tendermess of bovine muscle. J. Food Sci. 38:404.

3. Brewer, M. S., Ikins, W. G. and Harbers, C. A. Z. 1992. TBA walues, sensory characteristics and volatiles in ground pork during long-term frozen storage : Effects of packing. J. Food Sci. 57:558.

4. Buege, J. A. and Aust, J. D. 1978. Microsomal lipid peroxidation. Methods Enzymol. 52:302.

5. Carlin, A. F. and Harrison, D. L. 1978. Cooking and sensory methods used in experimental studies on meat. Natl. Livestock and Meat Board. Chicago, Illinois.

6. Chung, K. S., Yoon, K. D., Hong, S. S. and Kwan, D. J. 1996. Antimutagenic and anticarcinogenic effect of Korean fermented soybean products (in Korean), The 1st International symposium proceedings on functional and physiolosical activities of Korean traditional soybeaan fermented foods, KonKuk Univ. 3.

7. Crespo, F. L., Millian, R. and Serrani Moreno, A. 1978. Chemical changes during ripening of spanish dry sausage(Salchichon) III Changes in water-soluble N compounds. Archivos de Zootecnia. 27:105.

8. Decker, E. A. and Shantha, N. C. 1994. Concentrations of the anticarcinogen, conjugated linoleic acid, in beef. Meat Focus International. 3:61.

9. Dierick, N., Vandekerckhove, P. and Demeyer, D. 1974. Changes in nonprotein nitrogen compounds during dry sausage ripening. J. Food Sci. 39:301.

10. Du, M., Ahn, D. U. and Sell, J. L. 2000. Effect of dietary conjugated linoleic acid(CLA) and linoleic/ linolenic acid ration on polyunsaturated fatty acid status in laying hens. Poultry Sci. 79:1749.

11. Engler, N. M., Karanian, J. W. and Salem, J. M. 1991. Influence of dietary polyunsaturated fatty acids on aortic and plate fatty acid composition in the rat. Nutr. Res. 11:753.

12. Folch, J., Lees, M. and Sloane Stanley, G. H. 1956. A simple method for the isolation and purification of total lipides from animal tissues. Journal of Biological Chemistry. 226:497.

13. Greene, B. E., Hsin, I. and Zipser, M. W. 1971. Retardation of oxidative color changes in raw ground beef. J. Food Sci. 36:940.

14. Joo, S. T., Lee, J. I., Ha, Y. L. and Park, G. B. 2002. Effects of dietary conjugated linoleic acid on fatty acid composition, lipid oxidation, color and water-holding capacity of pork loin. J. Ani. Sci. 80:108.

15. Kim, I. S., Min, J. S. and Lee, M. 1998. Comparison of TBA, VBN, fatty acids composition, and sensory characteristics of the imported and domestic Frozen pork bellies. Korean J. Anim. Sci. 40(5):507.

16. Mottram, D. S. and Edwards, D. S. 1983. The role of triglycerides and phospholipids in the aroma of cooked beef. J. Sci. Food Agr. 34:517.

17. Pearson, C, K. and Barnes, M. M. 1970. The absorption and distribution of the naturally occurring tocohromanols in the rat. Brit. J. Nutr., 24: 581.

18. SAS. 1999. SAS/STAT Software for PC. Release 6.11, SAS institute, Cary, NC, U.S.A.

19. Savell, J. and Cross, H. R. 1988. The role of fat in the palatability of beef, pork, and lamb. In Designing foods: Animal Product Options in the Market Place(p. 345). Washington, DC: National Academy Press.

20. Sim, J. S. 1997. Designer eggs and their nutritional and functional significance. World Review of Nutrition and Dietetics. 83:89.

21. Whitaker, J. R. 1978. Biochemical changes occuring during the fermentation of high protein foods. Food Technol. 32:175.

22. Wu. F. Y. and Smith S. B. 1987. Ionic strength and myofibrillar protein solubilization. J. Anim. Sci., 65:597.

23. 高坂和久肉製品の と測定 食品 工業 18:105.

24. 김기태, 황용일, 임성일, 이동선. 2000. 포장된 전 통 된장 및 고추장의 저장 중 $\mathrm{CO}_{2}$ 발생과 특성 변화. 한국식품영양과학회지. 29:807.

25. 김일석, 민중석, 이상옥, 신대근, 이정일, 변준석, 이무하. 1998. 국내산 진공포장 냉장 돈육 뒷다 리육의 이화학적 및 관능적 특성. 한국축산식품 
학회지. 18:132.

26. 신동화, 김동한, 최웅, 임대관, 임미선. 1996. 전 통 고추장의 맛성분. 한국식품과학회지. 28:152.

27. 이종수, 권수진, 정성원, 최영준, 유진영, 정동효. 1996. 한국 재래식 된장과 고추장의 숙성 중 미 생물, 효소활성 및 주요 성분의 변화. 한국산업 미생물학회지. 24:247.

28. 이종호, 김미혜, 임상선. 1991. 재래식 메주 및 된장 중의 항산화성 물질에 관한 연구. 제 1 보. 메주 발효 및 된장 중의 지질산화와 갈변. 한국
영양식량학회지. 20:148.

29. 이희봉. 1974. 한국산 향신료의 항산화 효과에 관한 연구. 충북대학교논문집. 제8집:173.

30. 한국영양학회. 1995. 한국인 영양 권장량. 6 차 개 정판. 서울

31. 한국육류유통수출입협회. 2003. 2003년 돈육수급 및 가격전망. No. 97.

32. 허영미. 1996. 배추김치의 항돌연변이 및 항암효 과. 부산대학교 석사학위논문.

(접수일자 : 2003. 12. 17. / 채택일자 : 2004. 3. 23.) 